\section{Inhibition of Urease Activity by Ascorbic Acid}

Asconbic acid has been found to have a marked inhibitory effect on urease activity. With some preparations of the enzyme, the formation of ammonia from urea is completely inhibited by a concentration of one part ascorbic acid in 200,000 , and 50 per cent inhibition is obtained with one part ascorbic acid per million. The inhibition is prevented by addition of cysteine.

The urease preparation used was obtained by shaking $0.2 \mathrm{gm}$. Arlco-Jack bean meal with $18 \mathrm{ml}$. distilled water and centrifuging. $0.5 \mathrm{ml}$. of the urease, 3 c.c. acetate buffer $p \mathrm{H} 5 \cdot 0$, ascorbic acid and cysteine hydrochloride added as $0 \cdot 1$ per cent solutions, and water to make a volume of $8.3 \mathrm{ml}$. were kept at $45^{\circ} \mathrm{C}$. for half an hour, and then $1.7 \mathrm{ml}$. of 3 per cent urea solution added, to give a total volume of $10 \mathrm{ml}$. The ammonia formed was estimated colorimetrically with Nessler's reagent, using a Hilger 'Spekker' photo-electric absorptiometer.

EFTRCT OF ASCORBIC ACID ON UREASE ACTIVITY.

\begin{tabular}{|c|c|c|}
\hline Ascorbic acid & $\begin{array}{l}\text { Concentration of } \\
\text { ascorbic acid }\end{array}$ & $\begin{array}{l}\text { Ammonia formed } \\
\text { in } 60 \text { minutes }\end{array}$ \\
\hline $\begin{array}{ll}0.0 & \text { (Control) } \\
1.0 & \text { mgm. } \\
0.1 & , \\
0.05 & , \\
0.02 \quad ", \\
0.01 \quad, "\end{array}$ & $\begin{array}{rrr} & & \\
1 \text { in } & 10,000 \\
1 & , & 100,000 \\
1 & \prime \prime & 200,000 \\
1 & \Rightarrow & 500,000 \\
1 & \Rightarrow & 1,000,000\end{array}$ & $\begin{array}{cc}13 \cdot 4 & \text { mgm. } \\
0 \cdot 0 \quad, \\
0 \cdot 0 \quad, \\
0 \cdot 0 \quad, \\
3 \cdot 2 \quad, \\
6 \cdot 2 \quad,\end{array}$ \\
\hline
\end{tabular}

EFFECT OF OYSTEINE AND ASCORBIC ACID ON UREASE ACTIVITY

\begin{tabular}{|c|c|c|}
\hline Ascorbic acid & Cysteine hydrochloride & $\begin{array}{l}\text { Ammonia formed } \\
\text { in } 60 \text { minutes }\end{array}$ \\
\hline $\begin{array}{l}0 \text { (Control) } \\
0 \\
1 \text { mgm. } \\
1 \quad \text { ", } \\
1 \quad ", \\
1 \quad ", \\
1 \quad, \\
1 \quad, \\
1 \quad ", \\
1 \quad "\end{array}$ & $\begin{array}{cc}0 \cdot 0 & \text { mgm, } \\
2 \cdot 0 & , \\
0 \cdot 0 & , \\
2 \cdot 0 & , \\
1 \cdot 0 & , \\
0 \cdot 5 & , \\
0 \cdot 2 & , \\
0 \cdot 1 & , \\
0 \cdot 05 & , \\
0 \cdot 01 & ,\end{array}$ & 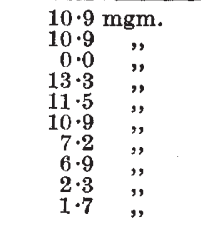 \\
\hline
\end{tabular}

My thanks are due to I.C.I. (Dyestuffs), Ltd., for permission to publish this letter.

L. A. Elson.

The Chester Beatty Research Institute,

The Royal Cancer Hospital (Free),

London, S.W.3. June 4.

\section{Mechanism of Polysaccharide Production from Sucrose}

IT has been shown that suitable bacterial cell extracts may act on sucrose with formation of a polyglucoside, dextran ${ }^{1,2}$, or of a polyfructoside, levan ${ }^{3}$. As instances of enzyme-mediated polymer syntheses in vitro, these reactions command wider interest than would necessarily alone be merited by the functional importance of levan and dextran in microbe and plant metabolism. The enzymes responsible for production of levan and dextran from sucrose will conveniently be designated, in accordance with the substrate requirement and reaction end- product of the enzyme agent employed, respectively as levansucrase and dextransucrase. It is the former enzyme, as it appears in autolysate fluid of a selected Aerobacter strain ${ }^{3}$, which is the subject of the present communication.

Levansucrase acts on sucrose or raffinose with production of levan and reducing sugar. All other substrates so far tested, including, in addition to common hexoses and disaccharides, several substrates with a terminal fructofuranoside group, namely, Neuberg ester, Harden-Young ester, methyl gamma fructoside, and inulin, failed to support levan production.

In its general properties, levansucrase is not unlike an ordinary carbohydrase. Its solutions are stable for months if kept on ice; when boiled they are immediately inactivated. The enzyme shows optimal activity at $p \mathrm{H} \mathbf{5 \cdot 5}$. It develops half-maximum synthesis velocity on sucrose concentrations between 0.02 and 0.06 molarity, the exact point depending on the enzyme lot. Glucose retards levan production to an extent dependent on its concentration relative to sucrose ; fructose, on the other hand, is completely non-retarding. Dialysis of the enzyme does not affect its activity as measured in citrate buffer on sucrose.

It has been shown that levan production from sucrose and raffinose can be described by a common formula :

$(n+m)$.aldosido $<>$ fructofuranoside $+n \cdot \mathrm{H}_{2} \mathrm{O} \rightarrow$

$(m+n)$.aldose $+n$.fructopyranose + [levan] . . (1)

where aldose is either glucose or melibiose, depending on whether sucrose or raffinose is the substrate employed, $m$ and $n$ are whole numbers experimentally determined, and where [levan] represents $m$ residues of fructofuranose polymerized to molecules of levan.

Galactose is not liberated by the enzyme from raffinose concomitantly with levan production. As is implicit in (1), therefore, production of levan from raffinose cannot be regarded as proceeding via intermediately formed sucrose.

The ratio $m / n$ characterizes the synthesizing efficiency of sucrose conversion by the tested enzyme system. Its magnitude varied, depending on the conditions of the experiment and on enzyme lot, between $0 \cdot 7$ and $1 \cdot 6$.

Levan production does not proceed unchecked in the direction indicated in (1). After an initial rapid advance, it is progressively slowed. On adequate sucrose amounts, and using cell-free soluble levansucrase as synthesizing agent, levan production always came to a stop once the concentration of levan was between 300 and $500 \mathrm{mgm}$. per cent, the value being variable within these limits with enzyme lot. New simultaneous addition of enzyme and sucrose to mixtures in which levan production had come to a stop failed to renew the synthetic process.

It should be observed that the measured end-point is not one of mass equilibrium between the saccharide reactants noted. Increase in the initial concentration of sucrose beyond a necessary minimum does not bring about a shift in the position of the levan end-point. Moreover, reversal of the direction of the enzyme's activity has not so far proved feasible. Although intact cells of the selected Aerobacter strain are themselves able to ferment levan slowly, soluble cell-free levansucrase preparations failed completely to act either on levan alone or on mixtures of levan and glucose in any chemically evident way.

Balance sheet experiments revealed no drop in 